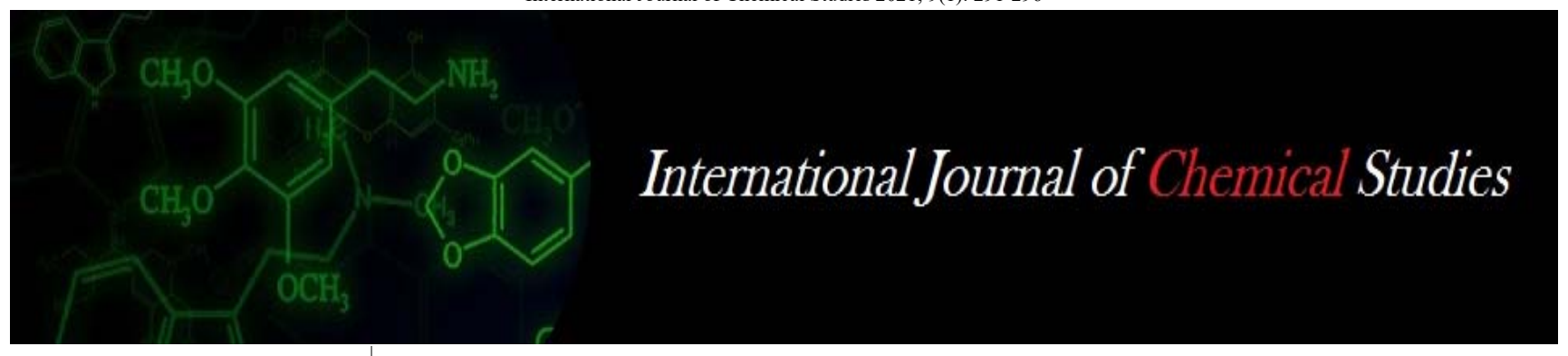

P-ISSN: 2349-8528 E-ISSN: 2321-4902 www.chemijournal.com IJCS 2021; 9(1): 291-296 (C) 2021 IJCS

Received: 10-12-2020 Accepted: 29-12-2020

Ashay D Souza

Ph.D., Scholar, Department of Soil Science and Agricultural

Chemistry, UAS, Dharwad,

Karnataka, India

Patil PL

Professor, Department of Soil Science and Agricultural Chemistry, UAS, Dharwad, Karnataka, India

Corresponding Author: Ashay D Souza Ph.D., Scholar, Department of Soil Science and Agricultural Chemistry, UAS, Dharwad, Karnataka, India

\title{
Soil suitability assessment for sustainable production of Cereals in Kanamadi South Subwatershed
}

\section{Ashay D Souza and Patil PL}

DOI: https://doi.org/10.22271/chemi.2021.v9.i1d.11243

\section{Abstract}

A soil suitability evaluation of Kanamadi South sub-watershed in the Northern Dry Zone of India was undertaken in the present study to define the soil fitness for the production of maize, pearl millet, and sorghum, the three major kinds of cereal that are widely grown in the area. The soils of Kanamadi south sub watershed were grouped into 19 mapping units. The mapping units of the study area were moderately (S2) to marginally suitable (S3) for maize. The suitability of the study area for pearl millet was found to be highly suitable (S1) to marginal (S3) suitable for pearl millet. The mapping units of the study area were high to marginally suitable for growing sorghum. Appropriate soil fertility management recommendations through an integrated soil fertility management approach should be applied to address these limitations as their lack of attention could affect the availability and uptake of nutrients by these crops in the study area.

Keywords: Kanamadi South sub-watershed, mapping unit, marginally suitable, moderately suitable

\section{Introduction}

Land suitability assessment is a prerequisite to achieving optimum utilization of available land resources for agricultural production in a sustainable manner. FAO (1976) ${ }^{[5]}$ defined land suitability as 'a function of crop requirements and land characteristics as well as a measure of how well the qualities of a land unit matches the requirements of a particular form of land use'. Land suitability assessment allows identifying the main limiting factors of a piece of land for particular crop production and enables decision-makers to develop a crop management system for increasing land productivity. (Denis et al., 2016) ${ }^{[4]}$.

Information on soil and related properties obtained from the soil survey and soil classification can help in better delineation of soil suitability for crops. The performance of any crop is largely dependent on soil properties such as depth, drainage, texture, etc., as conditioned by climate and topography (Bargali et al., 1993) ${ }^{[3]}$. The study of the soil-site characterization for predicting the crop performance of an area forms a part of the land evaluation process (Arora et al., 2011) ${ }^{[2]}$. According to FAO (1976) ${ }^{[5]}$, land evaluation is the rating of soil for optimum returns per unit area. The yield influencing factors for important crops have to be evaluated and the results obtained may be applied for higher production of these crops through proper utilization of similar soils occurring elsewhere in similar agro-climate sub-region under scientific management practices (Khadse and Gaikwad, 1995) ${ }^{[6]}$. Information on soil-site suitability evaluation for maize, pearl millet, and sorghum is not available for the study area. The present study was therefore undertaken to unfold this information.

Kanamadi south subwatershed is located $39.2 \mathrm{~km}$ away from Vijayapura (Bijapur), headquarter town of Vijayapura District. This area lies in the Northern dry zone of Karnataka and has a hot arid ecosystem with hot and dry summers and mild winters (K4D2) and subregion 6.1 (K4Dd3) North Karnataka Plateau. Kanamadi South Subwatershed (Vijayapura taluk, Vijayapura district) is located in between $16^{\circ} 51^{\prime}-16^{\circ} 55^{\prime} 30^{\prime \prime}$ North latitudes and $75^{\circ}$ $21^{\prime}-75^{\circ} 26^{\prime} 30^{\prime \prime}$ East longitudes, covering an area of about 4170.17 ha, bounded by Kanamadi on the North, Bijjaragi on the East, Honawada on the South and Belagavi district on the West. The area receives an annual average rainfall of $711 \mathrm{~mm}$ distributed over May to October. 


\section{Material and Methods \\ Soil Survey}

A detailed soil survey of the Kanamadi south sub-watershed was carried out using IRS P6 LISS-IV image and Vijayapura district Toposheet. The image and scanned Toposheet were geocoded and a subset was created in ArcGIS 10.2 on a 1: 12,500 scale. The area was then intensively traversed and 19 pedon locations were fixed on soil heterogeneity. At each pedon location, a fresh profile was opened and detailed morphological studies as described by the USDA Soil Survey Manual (2000) ${ }^{[11]}$ and horizon-wise samples were collected and analyzed for Physico-chemical parameters.

\section{Soil Mapping}

Based on soil heterogeneity as revealed by laboratory analysis and visual interpretation of the IRS P6 LISS-IV image, soil mapping units were delineated following the USDA Soil Survey manual (2000) ${ }^{[11]}$ and evaluated for the land capability and soil site suitability for crops.

\section{Soil Site Suitability evaluation for crops}

The FAO (1976) [5] framework for land evaluation was followed in the evaluation of soil-site suitability for maize, pearl millet and sorghum in the Kanamadi south subwatershed. This classification recognizes two orders of land suitability, order ' $\mathrm{S}$ ' (suitable) and order ' $N$ ' (not suitable) which are further subdivided into land suitability classes.

The classification includes four categories: orders, classes, subclasses, and units. There are two orders $(\mathrm{S}, \mathrm{N})$ that reflect the kind of suitability ( $\mathrm{S}$ for suitable and $\mathrm{N}$ for unsuitable). There are three classes (S-1 to 3) under the suitable order $\mathrm{S}$ and two classes (N-1 and 2) under the order N, reflecting the degree of suitability within the order. The appraisal of the classes, within an order, is done according to the evaluation of land limitations. The subclasses reflect the kinds of limitations or the main kinds of improvement measures required within a class. They are indicated by the symbol, using lower case letters following the arabic numeral used for the class. The land suitability unit suggests the relative importance of land improvement works. It is indicated by arabic numerals enclosed in parenthesis following the subclass symbol. The criteria for evaluation of soil suitability for maize, pearl millet, and sorghum are given in tables 1, 2 and 3 .

Table 1: Soil site suitability criteria (crop requirements) for Maize

\begin{tabular}{|c|c|c|c|c|c|c|}
\hline \multicolumn{2}{|c|}{ Soil site characteristics } & \multicolumn{5}{|c|}{ Rating } \\
\hline & & Unit & \begin{tabular}{|c|} 
Highly \\
suitable (S1)
\end{tabular} & $\begin{array}{c}\text { Moderately suitable } \\
\text { (S2) }\end{array}$ & $\begin{array}{c}\text { Marginally suitable } \\
\text { (S3) }\end{array}$ & $\begin{array}{c}\text { Not suitable } \\
(\mathbf{N})\end{array}$ \\
\hline \multirow[t]{2}{*}{ Climatic regime } & $\begin{array}{c}\text { Mean temperature in growing } \\
\text { season }\end{array}$ & ${ }^{\circ} \mathrm{C}$ & $21-32$ & \begin{tabular}{|r|}
$33-38$ \\
$15-20$ \\
\end{tabular} & $39-40<15$ & \\
\hline & \begin{tabular}{|l|} 
Total rainfall \\
\end{tabular} & $\mathrm{mm}$ & $900-100$ & $750-900$ & $500-750$ & $<500$ \\
\hline Land quality & Land characteristics & & & & & \\
\hline $\begin{array}{c}\text { Moisture } \\
\text { availability } \\
\end{array}$ & Length of growing period & Days & $>100$ & $100-80$ & $60-80$ & \\
\hline $\begin{array}{c}\text { Oxygen } \\
\text { availability to roots }\end{array}$ & Soil drainage & Class & Well drained & Mod. To imperfectly & Poorly/Excessively & V. poorly \\
\hline \multirow{4}{*}{ Nutrient availability } & Texture & Class & 1, cl, scl, sil & Sl, sicl, sic (c(n-s) & $\mathrm{C}(\mathrm{s}-\mathrm{s}), 1 \mathrm{~s}$ & \\
\hline & $\mathrm{pH}$ & $1: 2.5$ & $5.5-7.5$ & $7.6-8.55 .0-5.4$ & $8.6-9.0<5.0$ & \\
\hline & CEC & $\mathrm{c} \mathrm{mol}\left(\mathrm{p}^{+}\right) \mathrm{kg}^{-1}$ & $>20$ & $15-20$ & $10-15$ & \\
\hline & $\mathrm{OC}$ & \begin{tabular}{|c|}
$\%$ \\
\end{tabular} & High & Medium & Low & \\
\hline \multirow{2}{*}{ Rooting conditions } & Effective soil depth & $\mathrm{cm}$ & $>75$ & $50-75$ & $25-50$ & $<25$ \\
\hline & \begin{tabular}{|c|} 
Stoniness \\
\end{tabular} & $\%$ & Non gravelly & $15-35$ & $35-50$ & $>50$ \\
\hline \multirow{2}{*}{ Soil toxicity } & Salinity (EC saturation extract) & $\mathrm{dS} \mathrm{m}^{-1}$ & Non saline & $1.0-2.0$ & $2.0-4.0$ & \\
\hline & \begin{tabular}{|l|} 
Sodicity (ESP) \\
\end{tabular} & $\%$ & Non sodic & $10-15$ & $>15$ & \\
\hline Erosion hazard & Slope & $\%$ & $<3$ & 3.5 & $5-8$ & \\
\hline
\end{tabular}

Source: Naidu et al. (2006) ${ }^{[10]}$.

Table 2: Soil site suitability criteria (crop requirements) for pearl millet

\begin{tabular}{|c|c|c|c|c|c|c|}
\hline \multicolumn{2}{|c|}{ Soil site characteristics } & \multirow[b]{2}{*}{ Unit } & \multicolumn{4}{|c|}{ Rating } \\
\hline & & & $\begin{array}{l}\text { Highly suitable } \\
\text { (S1) }\end{array}$ & $\begin{array}{l}\text { Moderately suitable } \\
\text { (S2) }\end{array}$ & Marginally suitable (S3) & $\begin{array}{c}\text { Not suitable } \\
\text { (N) }\end{array}$ \\
\hline \multirow[t]{2}{*}{ Climatic regime } & $\begin{array}{l}\text { Mean temperature in growing } \\
\text { season }\end{array}$ & ${ }^{\circ} \mathrm{C}$ & $28-32$ & $\begin{array}{l}33-38 \\
24-27 \\
\end{array}$ & $\begin{array}{l}39-40 \\
20-23\end{array}$ & $<20$ \\
\hline & Total rainfall & $\mathrm{mm}$ & $500-750$ & $400-500$ & $200-400$ & $<200$ \\
\hline Land quality & Land characteristics & & & & & \\
\hline $\begin{array}{c}\text { Moisture } \\
\text { availability }\end{array}$ & Length of growing period & Days & $>90$ & $70-<90$ & $50-<70$ & \\
\hline $\begin{array}{l}\text { Oxygen } \\
\text { availability to } \\
\text { roots }\end{array}$ & Soil drainage & Class & Well drained & $\begin{array}{l}\text { Moderately well } \\
\text { drained }\end{array}$ & $\begin{array}{l}\text { Imperfectly drained; poorly } \\
\text { drained }\end{array}$ & \\
\hline \multirow{4}{*}{$\begin{array}{c}\text { Nutrient } \\
\text { availability }\end{array}$} & Texture & Class & sl, l, scl, sil, cl & ls, c, sicl, sc, c $<45$ & $\mathrm{c}>45 \%(\mathrm{SS}), \mathrm{s}$ & \\
\hline & $\mathrm{pH}$ & $1: 2.5$ & $6.0-8.0$ & $5.0-5.9 ; 8.1-8.5$ & $4.5-4.9 ; 8.6-9.5$ & \\
\hline & $\mathrm{CaCO}_{3}$ in root zone & $\%$ & $<5$ & $5-10$ & $10-25$ & $>25$ \\
\hline & $\mathrm{OC}$ & $\%$ & $0.50-0.75$ & $0.50-0.20$ & $<0.20$ & \\
\hline \multirow{3}{*}{$\begin{array}{l}\text { Rooting } \\
\text { conditions }\end{array}$} & Effective soil depth & $\mathrm{cm}$ & $>75$ & $51-75$ & $25-50$ & \\
\hline & Stoniness & $\%$ & $<15$ & $15-35$ & $>35-50$ & $>50$ \\
\hline & Coarse fragments & $\begin{array}{l}\text { Vol } \\
\%\end{array}$ & & & & \\
\hline
\end{tabular}




\begin{tabular}{|c|c|c|c|c|c|c|}
\hline \multirow{2}{*}{ Soil toxicity } & Salinity (EC saturation extract) & $\mathrm{dS} \mathrm{m}^{-}$ & $<1.0$ & $1.0-2.0$ & $2.0-4.0$ & $20-35$ \\
\cline { 2 - 7 } & Sodicity (ESP) & $\%$ & $<15$ & $15-20$ & $3-5$ & $5-10$ \\
\hline Erosion hazard & Slope & $\%$ & $<3$ & $3-5$ & $>10$ \\
\hline
\end{tabular}

Source: Naidu et al. (2006) ${ }^{[10]}$

Table 3: Soil-site suitability criteria (crop requirements) for sorghum

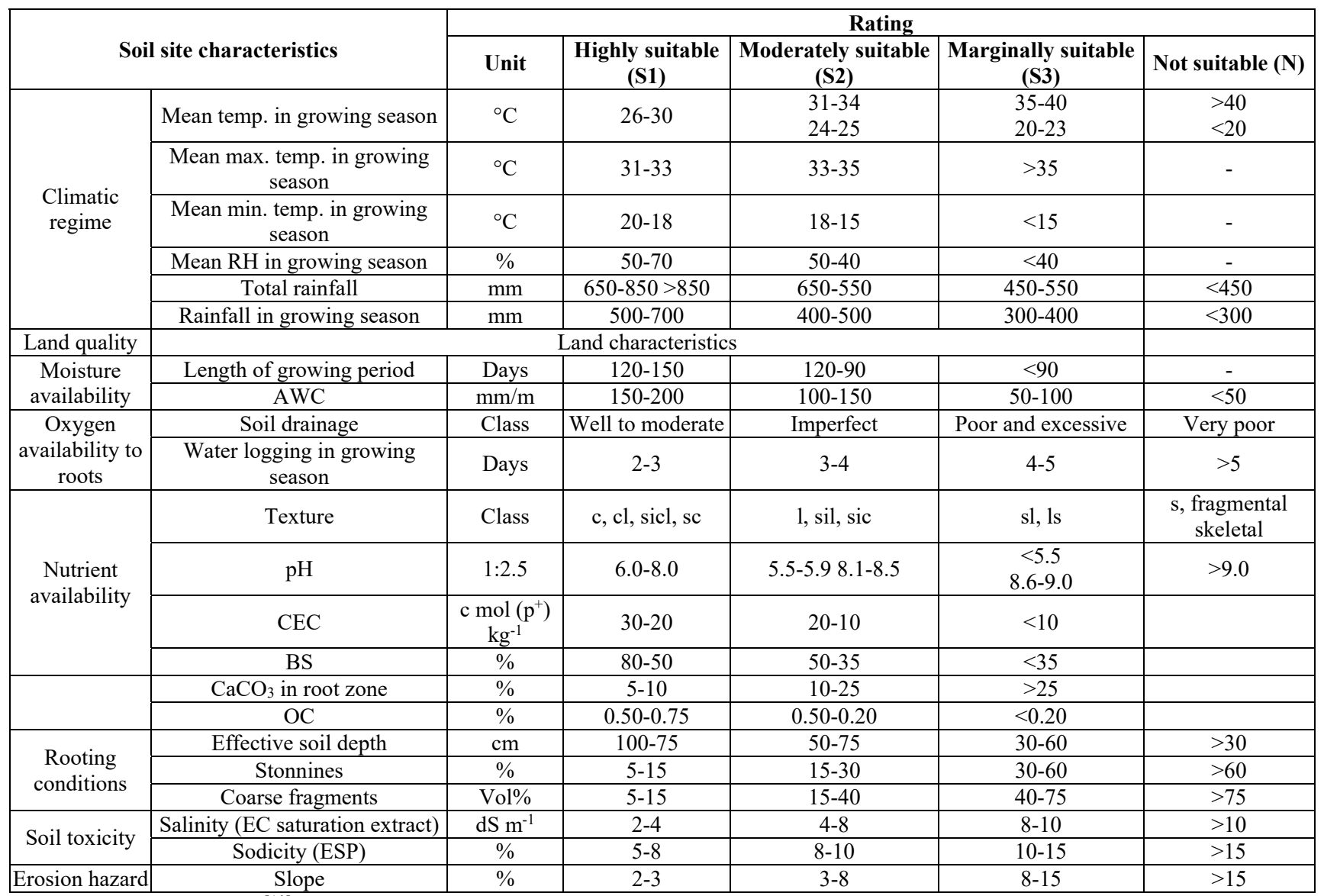

Source: Naidu et al. (2006) ${ }^{[10]}$

Table 4: Soil site suitability for cereals in Kanamadi south subwatershed

\begin{tabular}{|c|c|c|c|}
\hline Mapping units & Maize & Pearl millet & Sorghum \\
\hline DMTmB2g1 & S3s & $\mathrm{S} 3 \mathrm{~s}$ & $\mathrm{~S} 3 \mathrm{~s}$ \\
\hline DMTmB2g1Ca & $\mathrm{S} 3 \mathrm{~s}$ & $\mathrm{~S} 3 \mathrm{~s}$ & $\mathrm{~S} 3 \mathrm{~s}$ \\
\hline DMTmB2g2Ca & S3s & S3s & $\mathrm{S} 3 \mathrm{~s}$ \\
\hline KGRmB2 & $\mathrm{S} 2 \mathrm{~s}$ & $\mathrm{~S} 2 \mathrm{~s}$ & $\mathrm{~S} 2 \mathrm{~s}$ \\
\hline KGRmB2g1 & $\mathrm{S} 2 \mathrm{~s}$ & $\mathrm{~S} 2 \mathrm{~s}$ & $\mathrm{~S} 2 \mathrm{~s}$ \\
\hline NHLmB2 & S2s & $\mathrm{S} 2 \mathrm{~s}$ & $\mathrm{~S} 2 \mathrm{~s}$ \\
\hline THLmB2 & $\mathrm{S} 2 \mathrm{~s}$ & $\mathrm{~S} 1$ & $\mathrm{~S} 2 \mathrm{~s}$ \\
\hline THLmB2g1Ca & $\mathrm{S} 2 \mathrm{~s}$ & $\mathrm{~S} 1$ & $\mathrm{~S} 2 \mathrm{~s}$ \\
\hline THLmB2g2Ca & $\mathrm{S} 2 \mathrm{~s}$ & $\mathrm{~S} 1$ & $\mathrm{~S} 2 \mathrm{~s}$ \\
\hline RPRmB2 & $\mathrm{S} 2 \mathrm{~s}$ & $\mathrm{~S} 1$ & $\mathrm{~S} 2 \mathrm{~s}$ \\
\hline BBLmB2 & $\mathrm{S} 2 \mathrm{~s}$ & $\mathrm{~S} 1$ & $\mathrm{~S} 1$ \\
\hline NDNmB2 & $\mathrm{S} 2 \mathrm{~s}$ & $\mathrm{~S} 2 \mathrm{~s}$ & $\mathrm{~S} 2 \mathrm{~s}$ \\
\hline NDNmB2g1Ca & $\mathrm{S} 2 \mathrm{~s}$ & $\mathrm{~S} 2 \mathrm{~s}$ & $\mathrm{~S} 2 \mathrm{~s}$ \\
\hline TSLmB2g1Ca & $\mathrm{S} 2 \mathrm{~s}$ & $\mathrm{~S} 2 \mathrm{~s}$ & $\mathrm{~S} 2 \mathrm{~s}$ \\
\hline SRDmB2 & $\mathrm{S} 2 \mathrm{~s}$ & $\mathrm{~S} 1$ & $\mathrm{~S} 2 \mathrm{~s}$ \\
\hline SRDmB2g1Ca & $\mathrm{S} 2 \mathrm{~s}$ & $\mathrm{~S} 1$ & $\mathrm{~S} 2 \mathrm{~s}$ \\
\hline KRJmB2 & $\mathrm{S} 2 \mathrm{~s}$ & $\mathrm{~S} 2 \mathrm{~s}$ & $\mathrm{~S} 2 \mathrm{~s}$ \\
\hline KRJmB2g1Ca & $\mathrm{S} 2 \mathrm{~s}$ & $\mathrm{~S} 2 \mathrm{~s}$ & $\mathrm{~S} 2 \mathrm{~s}$ \\
\hline HNTmB2g1Ca & $\mathrm{S} 2 \mathrm{~s}$ & $\mathrm{~S} 1$ & $\mathrm{~S} 1$ \\
\hline
\end{tabular}

\section{Results and Discussion}

\section{Soil - site suitability for crops}

The climate and soil site characteristics play a significant role in maximizing crop yields. The suitability of cereals for each mapping unit was evaluated and results are presented in Table 4. The soil properties of the study area were matched with the soil site suitability criteria for important cereal crops (maize, sorghum and pearl millet) grown in study area. 


\section{Maize}

The mapping units of the study area were moderately (S2) to marginally suitable (S3) for maize. In general, maize requires an annual rainfall of $900 \mathrm{~mm}$; soil depth of $100 \mathrm{~cm}$ with sandy clay loam to clay texture (with $27-60 \%$ ), and good drainage. All the mapping units were marginally suitable with moderate to severe limitations of rainfall, depth, and organic carbon (Fig. 1).

The mapping unit KGRmB2, KGRmB2g1, NHLmB2, THLmB2, THLmB2g1Ca, THLmB2g2Ca, RPRmB2, BBLmB2 NDNmB2, NDNmB2g1Ca, TSLmB2g1Ca, SRDmB2, SRDmB2g1Ca, KRJmB2, KRJmB2g1Ca, HNTmB2g1Ca were moderately suitable (S2s) with moderate to severe limitation of $\mathrm{pH}$ and covered 3640 ha area $(87.29$ percent) of the sub-watershed area. An area of 482 ha (11.55 $\%$ of TGA) was marginally suitable (S3s) had moderate to severe limitation of organic carbon and $\mathrm{pH}$ and consists of the mapping unit DMTmB2g1, DMTmB2g1Ca, DMTmB2g2Ca. Similarly, moderate limitations of texture, depth, and drainage have also been reported by Manojkumar (2011) [9] in Bastawad micro-watershed of Northern transition zone of Karnataka and Manjunatha (2015) ${ }^{[8]}$ in Chikmageri micro watershed in Karnataka.

\section{Pearl millet}

The suitability of the study area for pearl millet was found to be highly suitable (S1) to marginal (S3) suitable for pearl millet (Fig. 2).

The suitability assessment for pearl millet revealed that the mapping unit HNTmB2g1Ca, BBLmB2, RPRmB2, SRDmB2, SRDmB2g1Ca, THLmB2, THLmB2g1Ca, THLmB2g2Ca were highly suitable (S1) and covered 1923 ha (46.10\% of TGA). The mapping unit KGRmB2, KGRmB2g1, NHLmB2, NDNmB2, NDNmB2g1Ca, TSLmB2g1Ca, KRJmB2, KRJmB2g1Ca were moderately suitable (S2s) had moderate to severe limitation of $\mathrm{pH}$, $\mathrm{CaCO} 3$, and organic carbon and covered 1717 ha $(41.18 \%$ of
TGA). An area of 482 ha (11.55\% of TGA) were marginally suitable $\mathrm{S} 3 \mathrm{~s}$ with moderate to severe limitation of $\mathrm{pH}$, organic carbon, and $\mathrm{CaCO} 3$ which included the mapping unit DMTmB2g1, DMTmB2g1Ca, DMTmB2g2Ca.

It is reported that soil depth of $>75 \mathrm{~cm},<10$ percent $\mathrm{CaCO} 3$, and clay texture are favorable for growing pearl millet. Mapping units in the sub-watershed were high to marginally suitable with limitations of soil characteristics for the production of pearl millet. Similar results were also reported by Madhusudan (2019) ${ }^{[7]}$ in the Kanaginahalla subwatershed, which was moderately suitable for pearl millet due to drainage and soil physio-chemical properties.

\section{Sorghum}

The mapping units of the study area were high to marginally suitable for growing sorghum (Fig. 3). The soil site suitability assessment for sorghum revealed that 270 ha $(6.47 \%$ of TGA) grouped under suitability sub class S1 and covered the mapping unit BBLmB2 and HNTmB2g1Ca. The data showed that 3370 ha $(80.82 \%$ TGA) had moderate to marginal limitations of severe limitation of $\mathrm{pH}$, stoniness, soil depth, and organic carbon and grouped as $\mathrm{S} 2 \mathrm{~s}$ and included the mapping unit KGRmB2, KGRmB2g1, NHLmB2, THLmB2, THLmB2g1Ca, THLmB2g2Ca, RPRmB2, BBLmB2, NDNmB2, NDNmB2g1Ca， TSLmB2g1Ca， SRDmB2, SRDmB2g1Ca, KRJmB2, KRJmB2g1Ca, HNTmB2g1Ca. Whereas, 482 ha ( $11.55 \%$ of TGA) having marginal to severe limitation of severe limitation of $\mathrm{pH}$, organic carbon, and stoniness and were grouped under the S3s suitability subclass (mapping units DMTmB2g1, DMTmB2g1Ca, DMTmB2g2Ca). It was observed that major constraints limiting sorghum production in the study area were organic carbon, depth, and stoniness. Similar results were reported by Manojkumar (2011) [9]. Anilkumar et al. (2019) [1] also reported most of the area of the Haradanahalli micro watershed was moderately suitable (S2) due to limitations of gravelliness, rooting depth, and calcareousness.

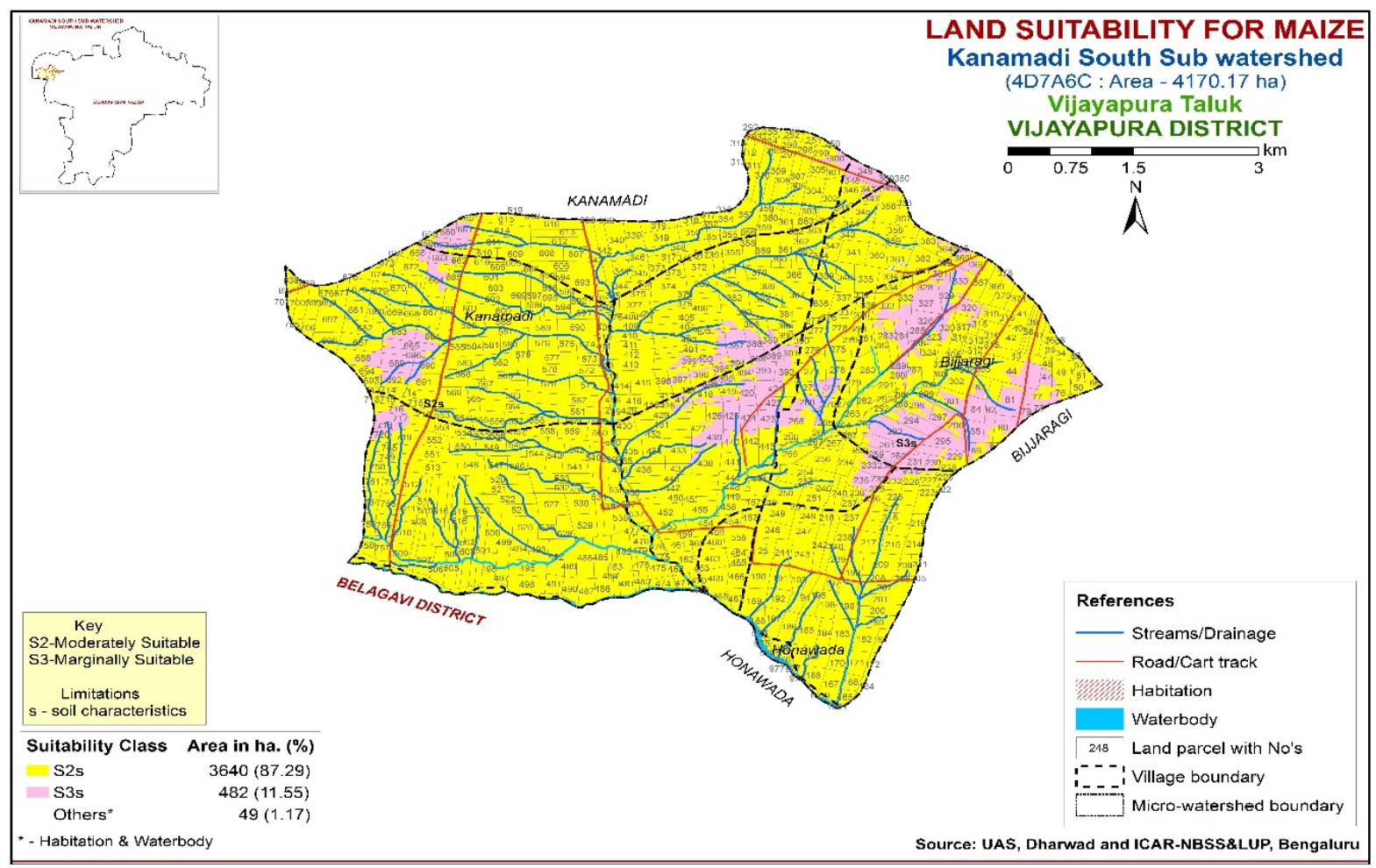

Fig 1: Soil suitability of Kanamadi south sub watershed for Maize 


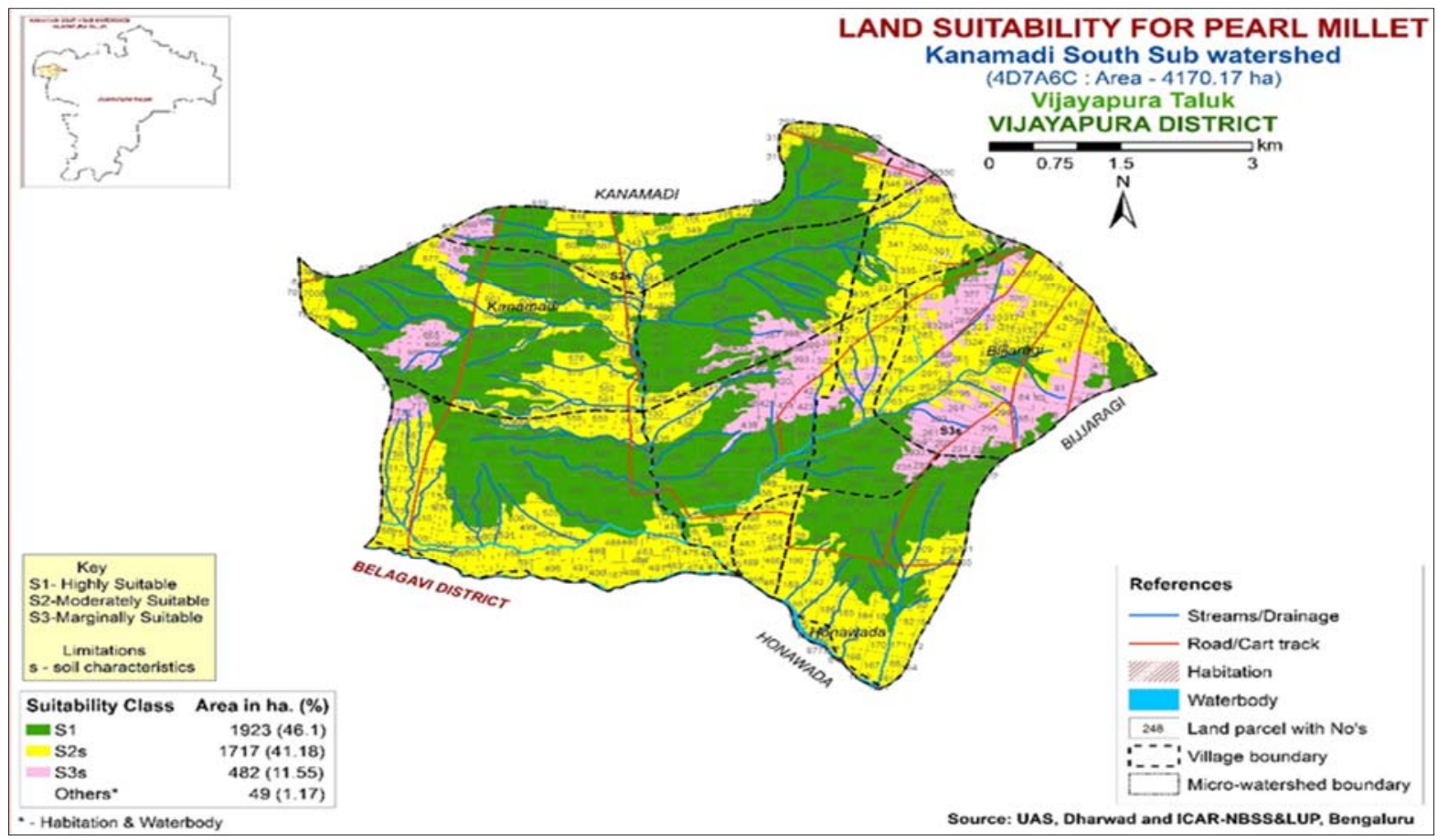

Fig 2: Soil suitability of Kanamadi south sub watershed for pearl millet

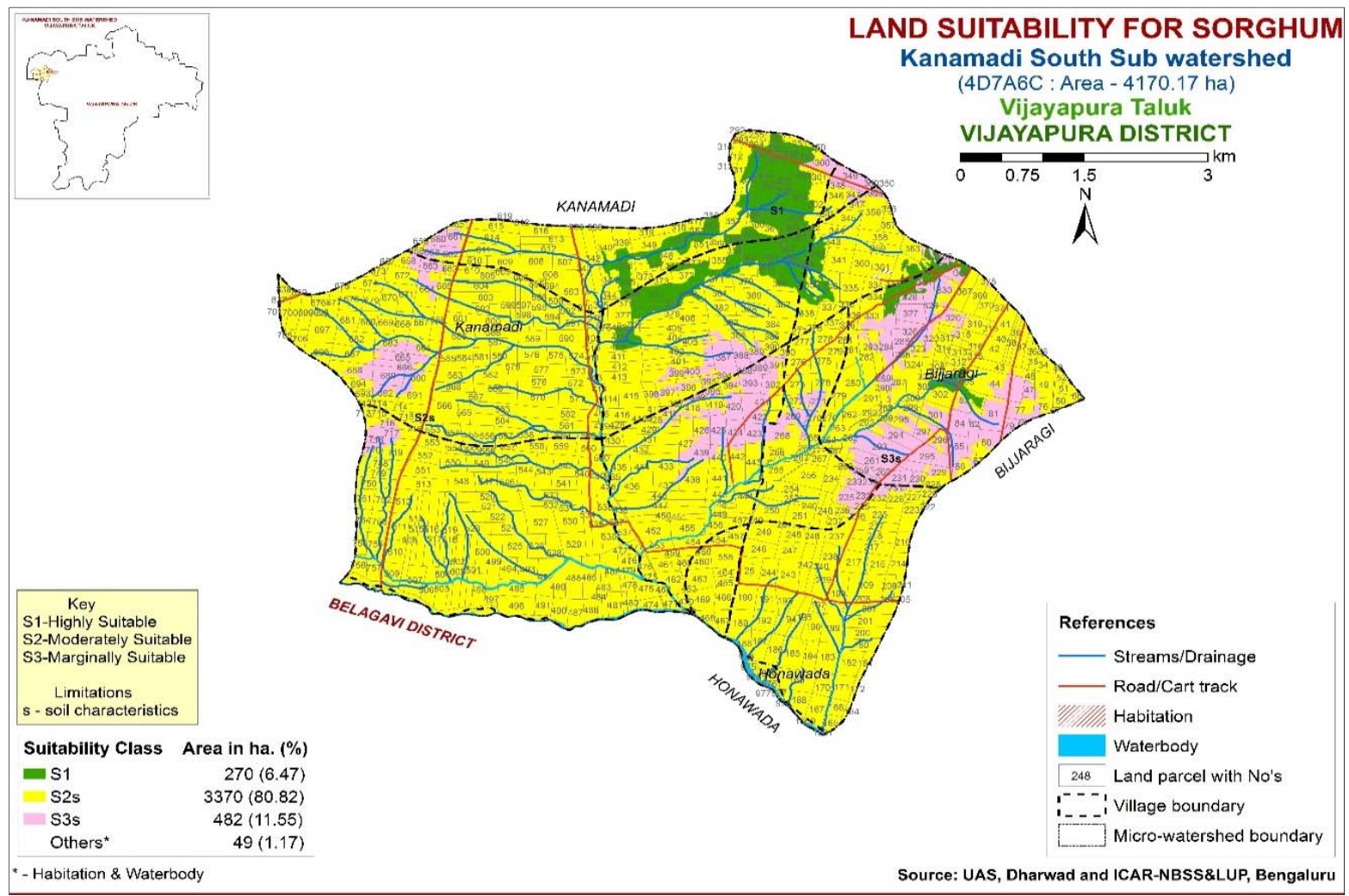

Fig 3: Soil suitability of Kanamadi south sub watershed for sorghum

\section{Conclusions}

Based on the soil suitability criteria, the mapping units were evaluated for growing cereal crops in the study area. The suitability evaluation revealed that more than 50 percent of the area was suitable for cereals like maize (S2, 87.29\% TGA), pearl millet (S1+S2, $87.28 \%$ TGA), sorghum (S1+S2, $87.29 \%$ TGA). Soil suitability assessment of cereals helped in identifying the main limiting factors of Kanamadi south subwatershed for cereal crop production and enables decision- makers to develop a crop management system for increasing land productivity.

\section{Acknowledgements}

I sincerely thank the SUJALA-III project staff of the University of Agricultural Sciences, Dharwad for helping in field and laboratory works to carry out this research work. The satellite image was obtained from KSRSAC- Bangalore. 
The criteria of land capability and soil suitability were followed as per NBSS \& LUP guidelines.

\section{References}

1. Anilkumar SN, Chikkaramappa T, Gopala YM, Arunkumar JS, Veerendra Patel GM. Soil Resource Inventory, Land Capability and Crop Suitability Assessment of Haradanahalli Micro-Watershed using Remote Sensing and GIS., Acta Sci. Agric 2019;3(3):129-137.

2. Arora VPS, Bargali SS, Rawat JS. Climate change: challenges, impacts, and role of biotechnology in mitigation and adaptation. Progressive Agric 2011;11:815.

3. Bargali SS, Singh RP, Mukesh, Joshi. Changes in soil characteristics in eucalyptus plantations replacing natural broad leaved forests. J Vegetation Sci 1993;4:25-28.

4. Denis, Magnus Ken Amara, Philip, Kamanda J, Parameshgouda, Patil L et al. Land suitability assessment for maize and paddy production in Bogur Micro watershed using remote sensing and GIS Techniques. Int. J Environ. Agric. Bio tech 2016;1(3):505-516.

5. FAO. A framework for land evaluation. FAO Soils. Bull. 32, Rome 1976,72p.

6. Khadse GK, Gaikwad ST. Soil based agro-technology transfer: A case study. Agropedology 1995,91-96.

7. Madhusudan. Studies on morphological, physical, chemical and mineralogical characteristics of Kanaginahala sub-watershed (4D7C3B) in northern dry zone of Karnataka, Ph. D Thesis, Univ. Agric. Sci., Dharwad, Karnataka, India 2019.

8. Manjunatha, Chari. Soil resource inventory of Chikmegeri-3 micro-watershed in Koppal district using remote sensing and GIS techniques. Ph. D Thesis, Univ. Agric. Sci., Dharwad, Karnataka, India 2015.

9. Manojkumar D. Characterization and classification of soils of a micro- watershed on basalt parent rock in northern transition zone of Karnataka. M. Sc. (Agri.) Thesis, Univ. Agric. Sci., Dharwad, Karnataka, India 2011.

10. Naidu LGK, Ramamurthy V, Challa O, Hegde R, Krishnan P. Manual Soil-Site Suitability Criteria for Major Crops, NBSS Publi. No. 129, NBSS and LUP, Nagpur 2006,118p.

11. USDA Soil Survey Staff manual. Soil Survey Manual. Soil Conservation Service. United States Department of Agriculture Handbook 18, Washington D.C., USA 2000. 